LETTERS TO THE EDITOR.

[The Editor does not hold himself responsible for opinions expressed by his correspondents. Neither can he undertake to return, or to correspond with the writers of, rejecten manuscripts intended for this or any other part of NATURE. No notice is taken of anonymous communications. ]

\section{A Biological Application of Röntgen Photography.}

THE accompanying Röntgen radiograph of Astropecten irregu. laris was made in the physical department of this college, for a popular lecture on the new photography given by Prof. H. Stroud. It will be seen that not only are the ossicles of the oral surface fairly successfully shown through the thickness of the body and arms, markedly the first of the series of adambulacra, but certain striking and unlooked-for objects appear as well. On dis section the dark conical body to the right proves to be a large piece of the shell of Dentalium lying in one of the creca of that arm. The oval bodies, one in each of the crca of the opposite arm, are masses of sand and indigestible material enclosed in the thinned shells of molluscan victims. These are made by the action of the cilia, and form a convenient way of getting rid of the useless matter by way of mouth. The minute anus, indeed,

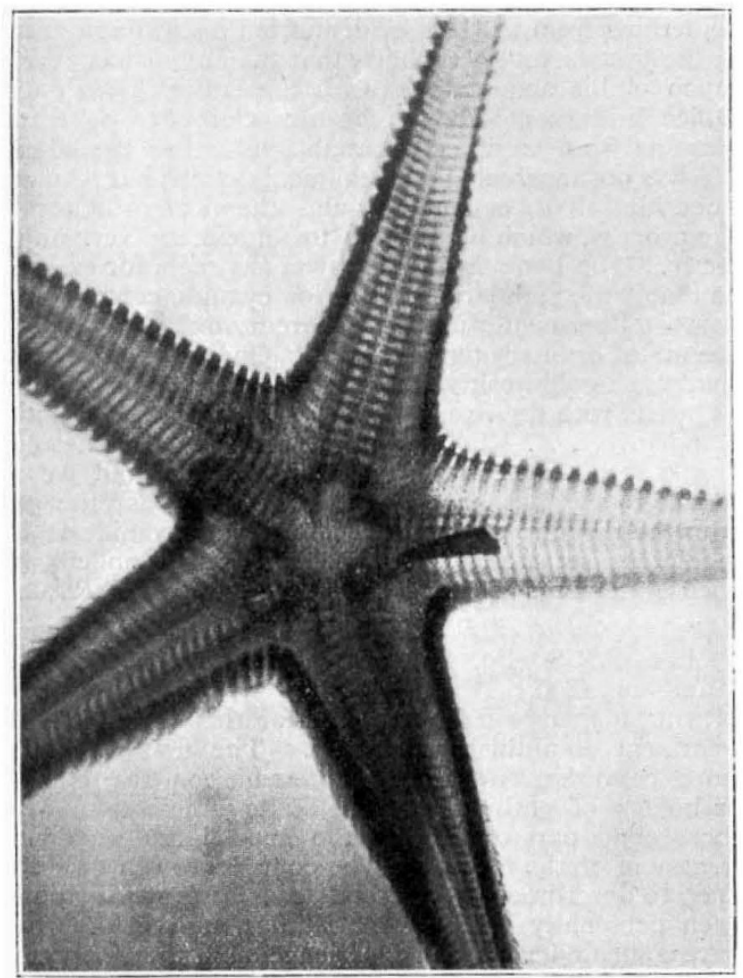

Astropecten irreguluris.

is quite inadequate, and is doubtless used more for fluid than solid evacuation. The madreporite plate and stone canal are seen in the inter-radius below and between the bodies referred to; and the position of the stone canal was in fact the guide in determining their position. The darkish mass in the cæcum to the left of the stone canal consists mainly of broken and whole shells of young Cardia. The stomach was filled with a whole common mussel (Mytilus edulis), minus the shell, and this is quite transparent. The paxillæ will be seen to occur as dots all over the body and arms. A block of wood, which was laid over part of the star-fish, has evidently only made a part of the picture lighter.

A radiograph of Solaster papposus, with the young Cribella, is enclosed for comparison. Though interesting also in regard to the skeletal parts shown, there is nothing calling for further note here, and they were not dissected.

NO. I 384 , VOL. 54$]$
All three were spirit specimens, and were got at St. Andrews some years ago.

Alexander Meek.

Durham College of Science, Newcastle-on-Tyne, April 25.

\section{Barisal Guns.}

IN the correspondence on this subject I have not noticed any reference to the noises said to be heard in the mountains of the peninsula of Sinai. In his "Sinai and Palestine" (ed. I868, pp. I3, I4), the late Dean Stanley refers to "the mysterious noises which have from time to time been heard on the summit of Jebel Musa, in the neighbourhood of Um Shaumer, and in a mountain of Nakus or the Bell, so called from the legend that the sounds proceed from the bells of a convent enclosed within the mountain. In this last instance the sound is supposed to originate in the rush of sand down the mountain side. . . . In the case of Jebel Musa, where it is said that the monks had originally settled on the highest peak, but were by these strange noises driven down to their present seat in the valley, and in the case of Um Shamer, where it was described to Burckhardt as like the sound of artillery, the precise cause has never been ascertained."

Burckhardt ("Travels in Syria and the Holy Land," I822, p. 59I) refers to these noises and says: "The wind and weather are not believed to have any effect upon the sound."

Failand, April 30.

EDW. FRY.

\section{The New Education Bill and Libraries, Museums,} and Art Galleries.

ReFerRING to the letter by "C." in NATURe for April 23 , p. 580 , I would urge the importance of his suggestion, but would go further and suggest that all institutions in England and Wales supported out of a rate raised under the Public Libraries Acts or the Museums and Gymnasiums Act, should be put under the management and control of the same local authority as may be appointed for elementary, technical and secondary education.

The management of educational institutions cannot be unified so long as such essentially educational work as that done in public libraries, museums, and art galleries does not come under the purview of the local education authority. There should, of course, be conditions inserted in any Bill having the object suggested to secure the expenditure of the rates received under the special Acts referred to, on the support of libraries, museums, art galleries and gymnasiums.

At present the Public Libraries Acts may be adopted and a rate levied, not one penny of which goes to the support of a library or museum. A certain Lancashire local authority applies the rate for purposes which would have been equally covered by the adoption of the Technical Instruction Acts. On the other hand, some public libraries and museums obtain subsidies out of the funds received by corporations under the Local Taxation (Customs and Excise) Act, though usually on condition that strictly educational books or objects are purchased out of the grants given.

I hope this subject will receive due consideration from such parliamentary advocates of scientific education as Sir John Lubbock and the members who act with him.

In conclusion, may I refer all who are interested in this sub. ject to a paper entitled " The Relationship of the Public Library Committee to other Educational Bodies," published in the Library (vol. vii. p. 129), the organ of the Library Association of the United Kingdom.

JOHN J. OGLE.

Free Public Library, Museum, and Technical School, Bootle, April 28.

\section{Magical Growth of Plants.}

I NOTICE in NATURE of April 9 that mention is made of the experiments of M. Ragonneau in connection with what is termed the magical growth of plants. At the time when M. Ragonneau's statements were first brought under my notice, I endeavoured as nearly as might be to repeat his experiments. I first used formic acid diluted $\mathrm{I} \cdot 5000$, the strength stated by M. Ragonneau as being that most successfully used by him. The soil was thoroughly dried, and was some which I had carefully prepared for growing Begonia seed. The seeds used were those of the Scotch thistle (Onopordiun Acanthium), a soft and easily-grown seed. The experiments were carried out in an ordinary greenhouse with temperature ranging from $55^{\circ} \mathrm{F}$. to $75^{\circ} \mathrm{F}$; ; and although I took every precaution to avoid mischance, the seeds have not to 